BIP: Jurna Bahasa Indonesia Prima,

Vol 3, No. 1, 2021, Maret 2021, pp.

\title{
PENANAMAN AJARAN AGAMA ISLAM TENTANG IBADAH SHOLAT LIMA WAKTU YANG DILAKUKAN OLEH ORANG TUA PADA ANAK DI KELURAHAN PEKAN GEDANG KECAMATAN BATANG ASAI KABUPATEN SAROLANGUN
}

Fransisko Chaniago ${ }^{1}$, Mohd. Norma Sampoerno ${ }^{2}$

Universits Islam Negeri Sulthan Thaha Saifuddin Jambi

Corresponding Author: fransiskopiliang@gmail.com

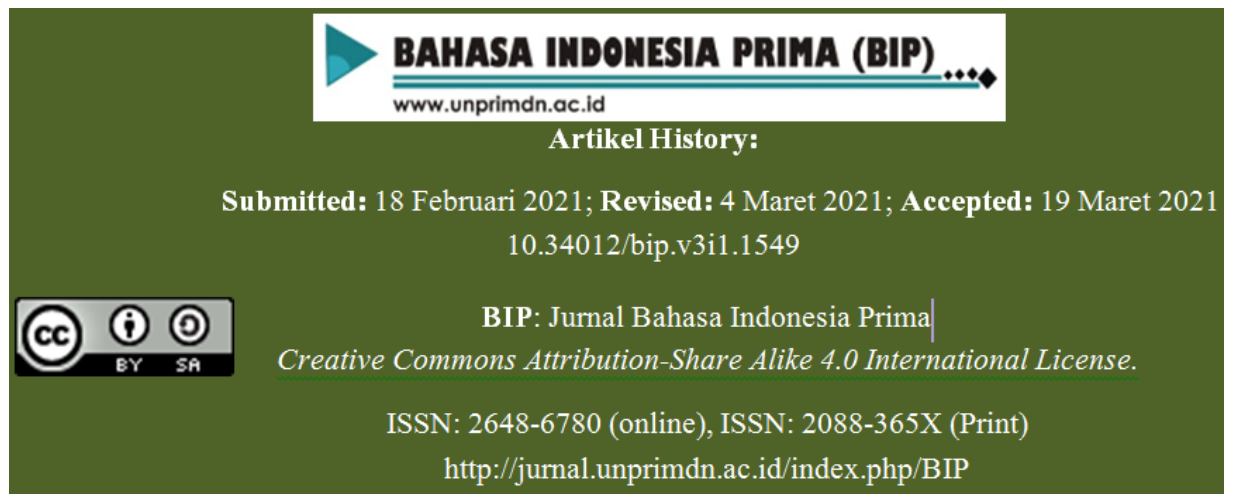

Abstrak-Jenis penelitian ini termasuk dalam jenis penelitian kualitatif dengan pendekatan studi kasus. Yakni kajian yang intensif, detil dan mendalam tentang suatu organisasi, institusi / fenomena tertentu. Hasil penelitian ini menemukan bahwa bentuk penanaman ajaran Islam yang dilakukan oleh orang tua pada anak di Desa Pekan Gedang Kecamatan Batang Asai Kabupaten Sarolangun yang ada dengan cara dibimbing dan diajar sendiri, kemudian dari dalam diri orang tua sendiri dengan memberi teladan atau menjadi teladan bagi anak di rumah, anak diasuh dan diberi nasehat, kemudian diajarkan melalui pembiasaan dan praktek, setelah itu langsung dipraktekkan, kemudian diberikan motivasi dan hukuman.

Kata Kunci: Usaha, Orang Tua, Ajaran Agama, Islam, Anak

Abstract-This type of research is included in the type of qualitative research with a case study approach. That is an intensive, detailed and in-depth study of an organization, a particular institution/ phenomenon. This research found that the form of instilling the teachings of Islam is carried out by parents in children in the PekanGedang Village, BatangAsai Subdistrict, Sarolangun Regency, which exists by being guided and taught by themselves, then from within the parents themselves by giving examples or being role models for children at home, children are nurtured and given advice, then taught through habituation and practice, after that it is practiced immediately, then given motivation and punishment.

Keywords: Efforts, Parents, Religious Teachings, Islam, Children

\section{A. Pendahuluan}

Anak adalah amanah dan karunia Allah SWT.Maka di dalam dirinya melekat harkat dan martabat sebagai manusia. Allah menanamkan fitrah yang suci, dengan fitrahnya tersebut ia akan menjadi permata bagi orangtuanya dan aset mereka kelak di kemudian hari. Pada masa anak terjadi proses pembentukan diri, baik secara biologis, psikologis maupun sosiologis yang sangat signifikan bagi 
tahap-tahap pertumbuhan dan perkembangan selanjutnya.

Banyaknya anak yang cenderung nakal, tidak sopan, suka berkata kasar, tidak disiplin, tidak mau bekerjasama dengan teman, malas beribadah dan tidak mau berperilaku hormat pada orang lain, pada saat ini telah menjadi keprihatinan para orangtua. Hal ini terjadi, selain karena proses pengasuhan dan pembinaan yang salah pada anak, juga akibat pengaruh buruk perkembangan teknologi informasi dan lingkungan yang kurang mendukung.

Perkembangan agama sejak usia dini memerlukan dorongan dan rangsangan sebagaimana pohon memerlukan air dan pupuk. Cara memberikan pendidikan atau pengajaran agama haruslah sesuai dengan perkembangan psikologis anak.Oleh karena itu dibutuhkan pendidik yang memiliki jiwa pendidik dan agamis, supaya segala gerak-geriknya menjadi teladan dan cermin bagi anak. ${ }^{1}$ Imam Ghazaly berpendapat bahwa pendidikan agama harus mulai diajarkan kepada anak sedini mungkin, pertama kali dengan mendidik hati mereka dengan ilmu pengetahuan dan mendidik jiwanya dengan ibadah. $^{2}$

Terkadang, orang tua atau pendidik dengan niat baik mengajarkan kepada anak-anak nilai-nilai agama, tanpa mengenal dengan baik kondisi kejiwaan dan mental mereka. Padahal kekeliruan ini akan membebani mental anak. Metode pendidikan agama untuk anak harus dikemas dalam bentuk sederhana dan penuh keceriaan, tapi metode ini harus berdampak positif bagi perilaku dan etika mereka.

${ }^{1}$ Zakiah Darajad. Remaja Harapan dan Tantangan. (Jakarta: Ruhana, 2005), hal. 127.

${ }^{2}$ Fathiyah Hasan Sulaiman.Sistem Pendidikan Versi Al-Ghazaly.(Bandung: Al-Ma'arif, 2003), hal 61.
Apabila nilai-nilai agama telah tertanam kuat pada diri seorang anak maka mereka akan tumbuh dan berkembang dengan memiliki kemampuan untuk mencegah dan menangkal serta membentengi diri mereka dari berbagai pengaruh yang negatif. Sebaliknya jika nilai-nilai keagamaan itu tidak ditanamkan dan dikembangkan secara maksimal maka akan muncul adalah perilaku-perilaku yang kurang baik dan cenderung menyimpang dari aturan agama. Kemudian juga terlihat bahwasaannya control serta didikan orang tua terhadap anaknya untuk melaksanakan sholat masih kurang disiplin terlebih lagi untuk memberi efek jera pada anak, padahal Nabi Muhammad SAW telah bersabda:

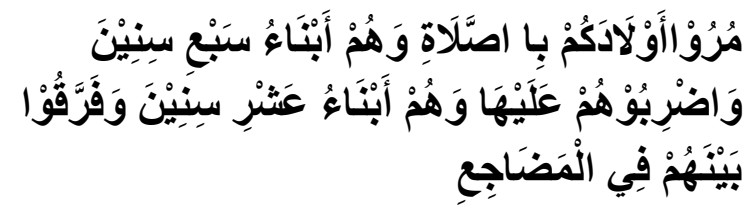

Artinya:Suruhlah anak kalian shalat ketika berumur tujuh tahun dan pukullah mereka ketika berusia sepuluh tahun (jika mereka meninggalkan shalat) dan pisahkanlah tempat tidur mereka (antara anak laki-laki dan anak perempuan (HR. Abu Dawud, no 495). ${ }^{3}$

Berdasarkan dari pengamatan yang dilakukan oleh penulis, terlihat bahwa sebagai orang tua menyadari bahwa tauladan mereka terhadap anak dirumah bisa mempengaruhi nilai keagamaan anak mereka dan mampu memotivasi anak mereka yang identik masih mencari contoh untuk diteladani. Para anak-anak juga kurang mengamalkan ajaran Islam, hal ini terlihat dari tingkah laku para anak-anak usia 7-10 tahun tersebut dalam kehidupan

${ }^{3}$ HR. Abu Dawud, no. 495; At-Tirmidzi, no. 407; Ad-Dârimi, I/333; Al-Hakim, I/201 dan lainnya, dari Sahabat Sabrah bin Ma'bad al-Juhani Radhiyallahu anhu. Dishahihkan oleh Syaikh alAlbani dalam Shahîh al-Jâmi'ish Shaghîr, no. 5867 dan Irwâ-ul Ghalîl, no. 247. 
BIP: Jurna Bahasa Indonesia Prima,

Vol 3, No. 1, 2021, Maret 2021, pp.

sehari-hari yang cenderung masih sering meninggalkan sholat, ketika waktu magrib sudah datang mereka masih asik bermain, ketika sedang sholat berjam'ah di masjid mereka mengganggu yang lain. Serta masih membutuhkan bantuan dan pengajaran serta contoh dari orang tua mereka.

\section{LANDASAN TEORI}

\section{Orang Tua}

Dalam penggunaan bahasa Arab istilah orang tua dikenal dengan sebutan Al-walid pengertian tersebut dapat dilihat dalam Al-qur'an surat Lukman ayat 14 yang berbunyi.

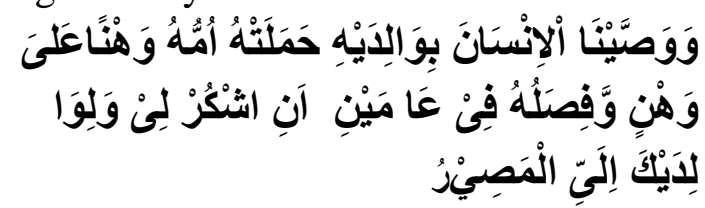

Artinya: Dan kami perintahkan kepada manusia (Berbuat baik) kepada dua orang ibu bapaknya ibunya telah mengandungnya dalam keadaan lemah yang bertambah-tambahdan menyapihnya dalam dua tahun, bersyukurlah kepada-Ku dan kepada dua orang ibu bapakmu, hanya kepada-Kulah kembalimu. (Q.S. Lukman ayat 14$)^{4}$

Seorang ayah dan ibu dari anakanak mereka tentunya memiliki kewajiban yang penuh terhadap keberlangsungan hidup bagi anak-anaknya, karena anak memiliki hak untuk diurus danan dibina oleh orang tuanya hingga beranjak dewasa. Orang tua merupakan dua diantara banyak orang yang mendidik tentang makna sebuah hidup dan kehidupan. Sebagai seorang muslim perlu mengetahui tata cara bergaul dengan orang tua. Hal ini dilakukan agar tidak terjerumus dalam kedurhakaan.

\footnotetext{
${ }^{4}$ Anonim. AlqurandanTerjemahannya. Q.S. Lukman ayat 14(Diponegoro: Yogyakarta 2008).
}

Berikut penjelasan tentang pengertian orang tua dalam kehidupan anak;

1. Orang tua adalah sekolah pertama bagi kehidupan anak. Dari orang tuanya, anak mendapatkan semua materi pelajaran kehidupan untuk pertama kalinya.

2. Orang tua adalah yang paling mengetahui anaknya. Karena itulah, ia adalah orang yang paling mengerti cara memaksimalkan pengembangan kecerdasannya.

3. Orang tua adalah pemegang amanah anak dari Tuhan. Karena itulah, ia menjadi pihak yang paling bertanggung jawab atas anaknya, termasuk dalam masalah pengembangan kecerdasannya. $^{5}$

Orang tua merupakan lembaga pendidikan tertua, bersifat informal, yang pertama dan utama dialami oleh anak serta lembaga pendidikan yang bersifat kodrati, orang tua bertanggung jawab memelihara, merawat, melindungi, dan mendidik anak agar tumbuh dan berkembang dengan baik.

\section{Ajaran Agama Islam}

Manusia disebut sebagai makhluk yang bergama (homo religious). Ahmad Yamani mengemukakan, bahwa tatkala Allah membekali insan itu dengan nikmat berfikir dan daya penelitian, diberinya pula rasa bingung dan bimbang untuk memahami dan belajar mengenali alam sekitarnya sebagai imbangan atas rasa takut terhadap kegarangan dan kebengisan alam itu. Dalam hal ini, agama senantiasa melibatkan apa yang "seharusnya"

${ }^{5}$ Redi Nugroho, Rosani Oktiviani. Menghormati Orang Tua. (Jakarta: PT. Karya Kita.2007) hal 1-3. 
dilakukan dan apa yang "senyatanya" diterimanya, karena memang dia merupakan dua sisi mata uang yang sama. Dengan kata lain, pesan yang terkandung di dalam firman Allah senantiasa memiliki dimensi mikro (hablum min Allah) dan dimensi makro (hablum min an-nas). ${ }^{6} \mathrm{Hal}$ inilah yang membuat penulis Prancis Edward Monet menyatakan: "Islam adalah agama yang pada dasarnya rasionalistis dalam arti seluas-luasnya.... Rasionalistis dalam arti sistem yang berdasarkan keyakinan-keyakinan pada prinsip-prinsip yang ditunjang rasio".

Adapun metode-metode yang dapat dipergunakan dalam kegiatan penanaman ajaran agama Islam tentang ibada hsholat pada anak ialah:

\section{Metode Pembiasaan}

Pembiasaana dalah sesuatu yang sengaja dilakukan secara berulang-ulang agar sesuatu itu dapat menjadi kebiasaan. Pembiasaan sebenarnya berintikan pengalaman, yang dibiasakan itua dalahsesuatu yang diamalkan. ${ }^{7}$

\section{Metode Cerita}

Metode bercerita adalah suatu metode yang mempunyai daya tarik yang menyentuh perasaan anak. Islam menyadari sifat alamiah manusia untuk menyenangi cerita yang pengaruhnya besar terhadap perasaan. Oleh karenanya dijadikan sebagai salah satu teknik pendidikan.

\section{Metode Karya Wisata}

Penerapan metode karya wisata sangat baik digunakan untuk menanamkan

\footnotetext{
${ }^{6}$ Jalaluddin, Psikologi Agama. (Jakarta: Raja GrafindoPersada.2008). Hal. 100.

${ }^{7}$ Mukharul Syafik, 2009, Metode Pembiasaan Sebagai Upaya Internalisasi Nilai Ajaran Islam, Diakses dari http:// masmukhorul. blogspot. com/2009/06/ metode-pembiasaan-sebagai upaya.html. pada tanggal 21 Agustus2020, jam
} 10.10 WIB jiwa keagamaan pada anak, karena dengan karya wisata anak didik akan mengetahui dan melihat secara langsung banyaknya dan indahnya ciptaan Tuhan Yang Maha Esa, selain itu pengalaman langsung dapat membuat setiap anak didik lebih tertarik kepada pelajaran yang disajikan sehingga anak didik lebih ingin mendalami ikhwal yang diminati dengan mencari informasi dari buku-buku sumber lainnya serta menumbuhkan rasa cinta kepada alam sekitar sebagai ciptaan Tuhan.Metode karya wisata berfungsi pula memberikan hiburan kepada anak didik dan rekreatif. (Syaiful Bahri Djamaroh, 2000: 202)

\section{Metode Keteladanan}

Ramayulis, (2002: 154) Metode keteladanan adalah metode pembelajaran dengan cara memperlihatkan keteladanan, baik yang berlangsung melalui penciptaan kondisi pergaulan yang akrab antara personal sekolah, prilaku pendidik dan tenaga pendidik lain yang mencerminkan akhlak terpuji maupun tidak secara langsung melalui sejumlah ilustrasi kisahkisah keteladanan.

\section{Metode Demonstrasi}

Metode mengajar dengan cara memperagakan barang, kejadian, aturan dan urutan melakukan sesuatu kegiatan, baik secara langsung maupun melalui penggunaan media pengajaran yang relevan dengan pokok bahasan atau materi yang sedang disajikan Muhibbin Syah, (2000: 203).

\section{Metode Tanya Jawab}

Metode tanya jawab merupakan metode mengajar yang memungkinkan terjadinya komunikasi langsung yang bersipat two way traffic sebab pada saat yang sama terjadi dialog guru dan siswa, guru bertanya siswa menjawab atausiswa bertanya guru menjawab, dalam komunikasi ini terlihat adanya hubungan 
timbal balik secara lansung antara guru dan siswa. ${ }^{8}$

\section{Ibadah Sholat}

$\begin{array}{rr}\text { becara } & \text { bahasa sholat bermakna } \\ \text { do'a, } & \text { sedangkan }\end{array}$ istilah, sholat merupakan suatu ibadah wajib yang terdiri dari ucapan dan perbuatan yang diawali dengan takbiratul ihram dan diakhiri dengan salam dengan rukun dan persyaratan tertentu. Menuruthakekatnya, sholat ialahmenghada pkan jiwa kepada Allah SWT, yang bisa melahirkan rasa takut kepada Allah \& bisa membangkitkan kesadaran yang dalam pada setiap jiwa terhadap kebesaran \& kekuasaan Allah SWT.

\section{Menurut Ash Shiddieqy,} sholat ialah menggambarkan rukhus shalat atau jiwa shalat; yakni berharap kepada Allah dengan sepenuh hati dan jiwa raga, dengan segala kekhusyu'an dihadapan Allah dan ikhlas yang disertai dengan hati yang selalu berzikir, berdo'a \& memuji-Nya.Dari Abu Abdurrahman, Abdullah bin Umar bin Khattab RA, dia berkata, "Saya mendengar Rasulullah SAW bersabda, 'Islam dibangun diatas lima perkara: bersaksi bahwa tiada tuhan selain Allah dan bahwa Muhammad adalah utusan Allah, menegakkan shalat, menunaikan zakat, melaksanakan haji dan puasa Ramadhan.” (HR. Bukharidan Muslim) ${ }^{9}$

\section{B. Metode Penelitian}

Penelitian ini menggunakan pendekatan kualitatif, sebagai upaya untuk memberikan jawaban atas permasalahan yang telah dibentangkan, karena sifatnya menggunakan pendekatan analisis

${ }^{8}$ Nana Sudjana, Dasar-Dasar Proses Belajar Mengajar, (Bandung Sinar Baru, AlGensindo,2010), hal, 78.

${ }^{9}$ (http://ahmadghozali.com/arbain-nawawi-haditske-3-rukun-islam/Akses 09 Juli 2020 22.30) deskriptif. Jenis penelitian ini termasuk dalam jenis penelitian kualitatif dengan pendekatan studi kasus. Yaitu suatu penelitian yang dilakukan secara intensif, terinci dan mendalam terhadap suatu organisasi, lembaga/gejala tertentu. Ditinjau dari wilayahnya, maka penelitian kasus hanya meliputi daerah atau subyek yang sangat sempit tetapi dari sifat penelitian, penelitian kasus lebih mendalam. ${ }^{10}$ Teknik pengumpulan data dalam penelitian ini menggunakan observasi, wawancara, dan dokumentasi. Setelah data terkumpul dengan lengkap dan benar, kemudian dilakukan dengan analisis data. Pemilihan metode ini didasarkan atas beberapa pertimbangan. Pertama, menyesuaikan metode kualitatif lebih mudah apabila berhadapan dengan kenyataan ganda; kedua, metode ini menyajikan secara langsung hakikat hubungan antara peneliti dengan responden; ketiga, metode ini lebih peka dan lebih bisa menyesuaikan diri dengan banyak penajaman pengaruh bersama dan terhadap pola-pola nilai yang dihadapi.

\section{HASIL TEMUAN DAN ANALISIS HASIL PENELITIAN}

Penanaman Ajaran Agama Islam Tentang Ibadah Sholat Lima Waktu yang dilakukan oleh Orang Tua pada Anak di Kelurahan Pekan Gedang Kecamatan Batang Asai Kabupaten Sarolangun

Penanaman ajaran keagamaan ibadah shalat lima waktu yang dilakukan oleh orang tua pada anak di Kelurahan Pekan Gedang Kecamatan Batang Asai dilakukan dengan berbagai macam cara, walaupun ilmu agama mereka minim, tetapi mereka tetap berusaha bagaimana

\footnotetext{
${ }^{10}$ SuharsimiArikunto. Prosedur Penelitian Suatu Pendekatan Praktek. Jakarta: Rineka Cipta.2005)hal 65.
} 
anaknya bisa mendapatkan pendidikan agama dengan baik, terutama dalammelaksanakanibadah shalat wajib 5 waktupadaanak. Berdasarkan hasil temuan yang dilakukanoleh penulis terlihat beberapa hal yang dilakukan oleh orang tua dalam meningkatkan nilai keagamaan shalat wajib pada anak, antara lain:

\section{a. Diajari dan dibimbing sendiri}

Upaya yang dilakukan oleh orang tua di kelurahan Pekan Gedang Kecamatan Batang Asai memulainya dengan mendidik anak-anak dari kecil, dengan memberikan contoh, menyuruh menghafal bacaanbacaan shalat, mengajarkan gerakangerakan shalat. Seperti yang dikatakan oleh salahsatuorang tua B yang menyatakan"Di rumah saya mengajarkan sendiri anak saya, mulai dari kecil ketika dia sudah mulai mengenal, saya mengajarkan gerakan-gerakan shalat, mulai dari takbiratul ihram sampai salam. Setelah itu baru kami mengajarkan bacaan shalat mulai dari niat sampai salam". ${ }^{11}$ Sebagaimana keterangan yang disampaikan oleh orang tua $\mathrm{K}$ sebagai berikut: "Mengajarkan bacaan-bacaan shalat memang merupakan pekerjaan pertama yang harus dilakukan orang tua, karena bila anak belum diajarkan bacaanbacaan shalat, maka dia akan merasa enggan melaksanakan shalat. Dia beranggapan untuk apa shalat kalau bacaannya saja belum hafal, lagipula mengajarkan bacaan-bacaan shalat tidak membutuhkan waktu-waktu khusus, kapan saja ada kesempatan bisa dilakukan tetapi kami biasa mengajarkan anak kami habis shalat maghrib setelah mengaji, setelah hafal bacaannya baru kami mengajarkan gerakannya". ${ }^{12}$ Selanjutnya orang tua D

\footnotetext{
${ }^{11}$ (wawancara,19Desember2020)

${ }^{12}$ (wawancara,19Desember2020)
}

mengatakan sebagai berikut:"Kami selaku orang tua senantiasa mengajarkan bacaanbacaan shalat kepada anak kami bahkan mulai dari awal sekali yakni cara mengambil air wudhu, kemudian do'anya baru kemudian diajarkan bacaan-bacaan shalat, mulai dari niat, kemudian bacaanbacaan yang lain, setelah itu baru kami mengajarkan gerakannya". ${ }^{13}$

Penulis memahami bahwa pembinaan shalat terhadap anak berawal dari keluarga, baru anak bisa melaksanakan shalat yang lebih baik itu karena perhatian orang tuanya. Orang tua bertanggung jawab dalam hal pembinaan serta perhatiannya dalam pembinaan pelaksanaan shalat wajib bagi anakanaknya. Usia enam tahun sampai sepuluh tahun. Sejalan dengan itu, kebijakan yang diberlakukan seorang ibu dan bapak. Dari pengamatan dan wawancara tersebut dapat dilihat bahwa orang tua dalam mendidik anaknya melaksanakan ibadah shalat diupayakan sejak kecil, sehingga setelah dewasa anaknya akan terbiasa melaksanakan ibadah shalat tanpa perlu diperintahkan lagi.

\section{b. Ketauladanan Orang Tua dalam mendidik anak dalam shalat}

Salah satu perhatian orang yang berada di Kelurahan Pekan Gedang Kecamatan Batang Asai ini setelah dengan diajari dan dibimbing, mereka melanjutkannya dengan ketauladanan, karena dengan demikian tentunya anak akan mendapat kesan positif dari orang tua dan secara tidak langsung akan memberikan pengaruh yang baik terhadap anak, besar kemungkinan anak akan tertarik untuk belajar melaksanakan shalat, karena melihat orang tuanya memberikan tauladan yang baik, hal ini sebagaimana

\footnotetext{
${ }^{13}$ (wawancara, 20Desember2020).
} 
hasil wawancara penulis dengan orang tua $\mathrm{Z}$ sebagai berikut: "Memang pada pertama-tama saya lakukan adalah memberikan ketauladanan kepada anak. Dalam hal ini mengenai ibadah shalat, tujuan saya agar tumbuh keinginan dalam diri anak saya melaksanakan shalat dan anak saya menjadi lebih termotivasi lagi untuk belajar melaksanakan shalat". ${ }^{14}$

Kemudian ditambahkan lagi oleh orang tua $\mathrm{R}$ mengatakan: "Saya memberikan ketauladanan kepada anak saya, untuk memberikan contoh perbuatan dalam melakukan shalat dan lebih mudah anak untuk belajar cara-cara shalat, setiap saya shalat anak saya melihat saya shalat dan ia tertarik untuk melakukan shalat, sehingga anak saya terbiasa tanpa saya suruh dan dia melakukan sendiri". ${ }^{15}$

Berdasarkan pengamatan yang penulis lakukan terhadap orang tua, ternyata dengan memberikan ketauladanan kepada anak-anak mereka menjadi lebih mudah untuk mendidik anak agar melakukan shalat, ini dibuktikan pada saat shalat maghrib, para orang tua pada sore harinya telah bersiap dengan peralatan shalat lengkap, baru orang tua tersebut memerintahkan atau mengajak anak-anak mereka shalat. Hal ini ternyata memberikan pengaruh positif terhadap anak-anak untuk melakukan shalat, artinya anak-anak mereka langsung melaksanakan perintah orang tuanya karena melihat orang tuanya telah besiap.Pembinaan dalam bentuk ketauladanan ini merupakan hal yang sulit dilakukan oleh seseorang, karena mencontoh atau meniru yang baik itu susah sekali tetapi kalau meniru perbuatan buruk ini sangat mudah sekali dan digemari orang. Keteladanan atau

${ }^{14}($ wawancara, 22Desember2020)
${ }^{15}($ wawancara, 22Desember2020) uswatun hasanah ini akan dapat membina dan membentuk watak dan kepribadian seseorang sesuai dengan ajaran-ajaran agama Islam dan bertindak serta memutuskan sesuai dengan norma-norma yang berlaku, maka yang pertama kali yang berbuat dalam bidang tingkah laku ataupun akhlak adalah kepala sekolah dan orang tua akidah akhlak.

\section{c. Pembinaan dengan metode nasehat}

Nasehat pada dasarnya menyampaikan pesan dari sumbernya kepada pihak yang memerlukannya, banyak dalam Al-qur'an berupa nasehat dan cerita mengenai para Rasul atau Nabi terdahulu sebelum Nabi Muhammad SAW yang bertujuan untuk menimbulkan kesadaran bagi yang mendengarkan atau yang membacanya, agar meningktkan iman dan takwa kepada Allah SWT. Nasehat ini merupakan bentuk pembinaan yang sangat sakral dalam membentuk kepribadian seseorang terutama dalam pembinaan pengamalan shalat anak, nasehat dan pengajaran ini sering diberikan ketika anak bercanda dalam shalat, lalai, dan dalam shalat bermainmain.

Seiring dengan persoalan di atas orang tua $\mathrm{K}$ menambahkan bahwa: "Nasehat ini langsung diberikan kepada anak yang berbuat salah dan melalaikan kewajiban, apabila ditunggu waktu lain untuk menasehatinya atau tidak ada pada saat itu juga, maka mengalami kelupaan baik pada anak maupun orang tua, dan anak tentu akan berbuat kesalahan yang serupa lagi". ${ }^{16}$ Senada dengan pernyataan orang tua $\mathrm{K}$, seperti yang diungkapkan oleh orang tua D mengatakan: "Jika anak sering melalaikan kewajibannya, maka

${ }^{16}$ (wawancara, 24Desember2020) 
tidak jarang kami selaku orang tua terus memberikan nasehat kepada mereka, supaya mereka bisa melakukan semua kewajiban dan perintah agama dengan baik. Karena kami tidak ingin anak-anak kami menjadi lalai terhadap kewajiban agama". ${ }^{17}$

Kemudian ditambahkan lagi oleh seorang guru Pami mengatakan P: "Nasehat selalu kami berikan kepada anakanak baik sebelum belajar atau sesudah belajar, karena anak-anak itu memang harus selalu diingatkan dan diberikan nasehat, supaya mereka tidak lalai. Karena anak-anak itu ibaratkan tanaman, selagi waktu muda harus diluruskan dan diingatkan. Kalau dia sudah beranjak dewasa maka akan semakin sulit untuk diingatkan". ${ }^{18}$

Berdasarkan pengamatan yang penulis lakukan terhadap orang tua, bahwa metode nasehat ini langsung diberikan ketika anak berbuat salah atau menantang apa yang diajarkan oleh orang tua, dengan tujuan supaya anak tidak membuat kesalahan yang serupa lagi.

\section{d. Mendidik melalui pembiasaan dan latihan}

Melaui pembiasaan dan latihan anak-anak akan aktif melakukan shalat dan mereka menjadi terbiasa untuk melakukan rutinitas ibadah shalat, hal ini dilakukan oleh orang tua, karena sebelum anak terdidik untuk mampu melaksanakan shalat dengan baik dan benar terlebih dahulu ada pembiasaan dan latihan yang ditanamkan oleh setiap orang tua artinya pada saat mereka diperintahkan untuk shalat, mereka telah terbiasa, hal ini sebagaimana hasil wawancara penulis dengan orang tua $\mathrm{N}$, sebagai berikut:

\footnotetext{
${ }^{17}$ (wawancara, 24Desember2020)

${ }^{18}$ (wawancara, 26Desember2020)
}

"Saya mengajarkan anak melalui pembiasaan dan merupakan pekerjaan saya sebagai orang tua. Saya melakukan pembiasaan dengan cara membiasakan anak melakukan shalat yang mudah dulu, misalnya membiasakan dengan mengajaknya melaksanakan shalat maghrib, saya beranggapan apabila dia sudah terbiasa melaksanakan shalat maghrib maka akan mudah apabila diajak untuk s tahui alasan para orang tua yang lebih memilih langsung mempraktekkan gerakan shalat dapat dilihat dari hasil wawancara penulis dengan orang tua $\mathrm{Z}$ sebagai berikut: "Saya mengajarkan anak saya shalat dengan melalui praktek langsung, mulai dari cara berdiri yang betul gerakan ruku', sujud dan duduk yang benar, karena bagaimana nanti ia dapat melaksanakan shalat dengan baik kalau gerakannya saja tidak tahu". ${ }^{19}$

Gerakan dan bacaan dapat dilaksanakan anak dengan baik, para orang tua untuk meluangkan waktunya mengajarkan shalat kepada anak-anaknya, untuk mengetahui intensitas perhatian orang tua dalam meluangkan waktu mengajarkan shalat kepada anaknya, dapat dilihat pada hasil wawancara orang tua A berikut: "Saya mengajarkan anak saya seminggu tiga kali juga secara tidak langsung mengajarkannya dengan mengajaknya berjama'ah langsung, baik itu dilakukan di rumah maupun di masjid. Dengan demikian anak saya, belajar dari apa yang dilihatnya, apalagi anak saya yang baru berumur 7 tahun, ia begitu bersemangat bila diajak shalat berjama'ah termasuk pada saat jama'ah shalat maghrib di musholla". ${ }^{20}$ Dari wawancara dengan orang tua N, mengatakan: "Sejak dini anak

\footnotetext{
${ }^{19}$ (wawancara, 26Desember2020)

${ }^{20}$ (wawancara, 26Desember2020).
} 
kami sering melihat dan memperhatikan kami shalat, kemudian kami mengajarkan mereka cara berwudhu, mengajarkan bacaan-bacaan dan mengajak mereka sholat bersama kami untuk dicontohkan kepada mereka, sampai mereka mengerti dan mulai mengerjakan shalat dengan sendiri-sendiri". ${ }^{21}$

Dari hasil pengamatan penulis dapat ditemukan bahwa orang tua yang mengajarkan anaknya dalam seminggu tiga kali bahkan sesekali mengajarkan anaknya secara langsung yaitu dengan mengajaknya shalat berjama'ah. Terlebihnya lagi sebagian besar orang tua, mendukung sepenuhnya pelaksanaan shalat bagi anak dengan baik dan benar, yakni dengan berupaya meluangkan waktunya dengan mengajarkan anak shalat melalui praktek langsung.

\section{e. Memberikan Motivasi dan Hukuman}

Upaya yang harus dilakukan oleh orang tua untuk memajukan dan meningkatkan nilai keagamaan anak pada shalat wajib adalah denga cara memberi motivasi dan hukuman kepada anak. Memberikan motivasi adalah merupakan salah satu cara untuk menimbulkan semangat belajar anak, tanpa adanya motivasi dari orang tuanya (keluarga), maka semangat belajar anak tidak akan tumbuh, oleh sebab itu motivasi dari orang tua sangat dibutuhkan oleh anak dalam menunjang keberhasilan belajarnya, karena makin bersemangat anak belajar dan menghafal bacaan-bacaan shalat maka akan semakin cepat ia bisa mengerjakan shalat dengan baik, sesuai dengan keterangan yang diperoleh dari wawancara dengan orang tua A: "Kami sebagai orang tua selalu berusaha memberikan dorongan

${ }^{21}$ (Wawancara, 26Desember2020). untuk belajar shalat, membina, membimbing dan memberikan saran serta nasehat dan pujian yang berguna bagi anak. Dengan harapan dapat menimbulkan semangat shalat anak". 22

Kemampuan shalat yang dimiliki anak berubah-ubah, tekadang rajin, terkadang malas, oleh karena itu sebagai orang tua harus senantiasa memberikan motivasi agar anak memiliki semangat yang tinggi untuk shalat. Adakalanya motivasi timbul dari kesadaran anak itu sendiri, dan ada juga atas dorongan atau pengaruh dari luar yang bersifat nasehatnasehat, bimbingan, hadiah dan hukuman. Seperti yang diungkapkan oleh orang tua $\mathrm{Z}$ berikut: "Saya dalam mendidik anak selain memberikan dorongan, nasehat dan bimbingan kadang-kadang dengan hukuman agar anak tetap mau shalat. Karena dengan nasehat, dorongan, bimbingan saja terkadang anak-anak tidak takut dan tetap malas, oleh sebab itu dengan hukuman seperti tidak boleh main/tidak diberi uang jajan nampaknya berhasil memotivasi anak-anak agar mau shalat". 23

Dari hasil wawancara di atas dapat dipahami bahwa orang tua di Kelurahan Pekan Gedang Kecamatan Batang Asai pada umumnya telah berusaha semaksimal mungkin mendidik anaknya melaksanakan Ibadah shalat. Anak perlu perhatian dari orang tua tentang pelaksanaan shalat, apabila sudah berumur sepuluh tahun kalau ia tidak mau mengerjakan shalat, maka berilah mereka hukuman, supaya mereka mau melaksanakan shalat.

\section{DAFTAR PUSTAKA}

Anonim. Alquran dan Terjemahannya. Diponegoro: Yogyakarta 2008.

\footnotetext{
${ }^{22}$ (wawancara, 28Desember2020).

${ }^{23}$ (wawancara, 28Desember2020).
} 
BIP: Jurna Bahasa Indonesia Prima,

Vol 3, No. 1, 2021, Maret 2021, pp.

Anonim. Kamus Umum Bahasa Indonesia. Jakarta: Balai Pustaka 2003.

Fathiyah Hasan Sulaiman.Sistem Pendidikan Versi Al-Ghazaly. Bandung: Al-Ma'arif. 2003.

HR. Abu Dawud, no. 495; At-Tirmidzi, no. 407; Ad-Dârimi, I/333; AlHakim, I/201 dan lainnya, dari Sahabat Sabrah bin Ma'bad alJuhani Radhiyallahu anhu. Dishahihkan oleh Syaikh al-Albani dalam Shahîh al-Jâmi’ish Shaghîr, no. 5867 dan Irwâ-ul Ghalîl, no. 247.

http://ahmadghozali.com/arbain-nawawihadits-ke-3-rukun-islam/Akses 09 Juli 2020.

Jalaluddin.Psikologi Agama. Jakarta: Raja GrafindoPersada. 2008.

Mukharul Syafik, 2009, Metode Pembiasaan Sebagai Upaya Internalisasi Nilai Ajaran Islam, Diakses dari http:// masmukhorul. blogspot. com/2009/06/ metodepembiasaan-sebagai upaya.html. pada tanggal 21 Juli2020, jam 10.10 WIB

Nana Sudjana, Dasar-Dasar Proses Belajar Mengajar, Bandung Sinar Baru, Al-Gensindo. 2010.

Redi Nugroho, Rosani Oktiviani. Menghormati Orang Tua. Jakarta: PT. Karya Kita. 2007.

Suharsimi Arikunto.Prosedur Penelitian Suatu Pendekatan Praktek. Jakarta: Rineka Cipta. . 2005.
Zakiah Darajad.Remaja Harapan dan Tantangan. Jakarta: Ruhana, 2005.

Djamarah, Syaiful Bahri.Guru dan Anak Didik dalam Interaksi Edukatif. Jakarta: Rineka Cipta. 2000. 